\title{
DEREK WALCOTT'S OMEROS AND THE CLASSICS
}

\author{
Richard Whitaker (University of Cape Town)
}

The Greek classics served the Italian, French, and English humanists without the troublesome interposition of actual Greeks. Texts by dead people were read, appreciated, and appropriated by people who imagined an ideal commonwealth ... In modern times, however, thinking about cultural exchange involves thinking about domination and forcible appropriation: someone loses, someone gains. (Edward Said 1994:235)

Is poetic epic still possible in the twentieth century? Many have felt that it is not, because of deep doubts they have about the way in which epic has been written in the past. Even Homer, despite his broad humanity and his evenhanded treatment of Greek and Trojan, composed an lliad that is filled with bloodshed and slaughter. Virgil, for all his anguished sympathy with the victims of Aeneas' 'mission', ultimately wrote from the viewpoint of a glorious, all-conquering Rome. And his Aeneid was easily appropriated by later epic poets such as Camoeñs, in the Lusiads, as a model for nationalistic poetry glorifying conquest and colonization. In this century the only major attempt at poetic epic in the English language, Ezra Pound's Cantos, has seemed the exception that proves the rule: an assemblage of glittering fragments rather than a unified poem, its anti-Semitic and fascist sentiments have alienated readers and seemed to confirm the dubious association of epic with ruling elites (Dassenbrock 1994).

Given this background it is not surprising that Derek Walcott's recently-published Omeros shows considerable ambivalence towards the Classics. Walcott has actually denied that his 325-page-long poem is an epic, despite its title, the fact that it conforms to Ezra Pound's definition of epic as "a poem including history" (Pound 1954:86), and the fact that the works to which it most consistently alludes are the Homeric epics, the Aeneid, Dante's Inferno and Joyce's Ulysses. I do not wish to debate the generic status of the poem. ${ }^{1}$ I shall argue that Walcott does indeed make epic possible again in the late twentieth century, but a very new kind of epic-one written from the standpoint not of the conquerors and colonizers, but of the conquered and colonized, an epic that constantly questions its own project and status. The poem's ambivalent relationship to the Greek and Roman Classics will be shown to be an essential part of its functioning.

What is Omeros about? The poem works on many levels and is 'about' many different things: exile, divided identity, the legacy of slavery and colonization, love,

1 Many critics do not seem to take Walcott's disclaimers too seriously; see, e.g., Taplin 1991:213: "undoubtedly epic"; Mason 1991:513: "Walcott's post-colonial epic"; Breslow 1993:267: "a rare modern verse epic". George Steiner (1993) too views Omeros as the latest item in an endless series of Anglo-American reworkings and translations of Homeric epic. 
personal suffering and loss and the possibility of redemption, the poet's relationship to his tradition. So rich and complex a poem is impossible to summarize; but since it will still be unfamiliar to many, I offer a brief account, however inadequate.

Omeros plays itself out chiefly in the Caribbean, in Castries, capital of Walcott's native St Lucia, a small island in the Lesser Antilles group. But for long stretches of the poem the characters are also transported in dream-vision or reality to other places: Africa, many countries of Europe, the USA. On the purely narrative level the poem tells of the love, rivalry and suffering of a group of islanders most of whom still bear the classical names-Achille, Helen, Hector, Philoctete-given half ironically to their slave-ancestors, brought over on the 'middle passage', from West Africa. (The mainly French forms of their names, and the fact that the islanders sometimes speak a French patois, reflect the colonial history of the island, which passed from French to English control in the later 18th century.) Other major characters native to the island are the blind singer, Seven Seas, and the 'sibyl' and obeah-woman, Ma Kilman, proprietor of the 'No Pain Cafe'. The poem focuses too on an expatriate British couple, the retired Regimental Sergeant-major, Dennis Plunkett, and his wife, Maud, he from England, she from Dublin. Finally, much of the poem is mediated to us by a narrator, who travels widely, only to return in the end to his native St Lucia. ${ }^{2}$

At one level Omeros clearly allegorizes. The poem makes great play with the fact that the island, St Lucia, was once called (St) Helen ${ }^{3}$-the name too of the major woman character of the poem, whom Achille, Plunkett, Hector, and even the narrator love, each in his own way. Walcott handles this with great delicacy, but crudely put, ${ }^{4}$ in terms of the allegory the main characters represent different elements of the island's population, and their relations to Helen the relations of these elements to their island. At this level, Achille embodies St Lucia's traditionalist inhabitants of African origin, Plunkett the formerly colonial, now settled expatriate element, and Hector the modernizing blacks, caught between the old ways and a new, exciting, but dangerous, technological lifestyle. The allegory breaks surface when Hector sells his traditional canoe and acquires a new 'transport' (what we in South Africa would call a minibus taxi), with "stereo, leopard seat". The passengers

2 Omeros is divided into seven Books and LXIV chapters, each chapter further subdivided into sections. I shall refer to specific passages as follows: 'LXIV/iii/6', where the first numeral indicates the chapter, the second the section, and the third the page of the Faber edition.

"The island was once / named Helen" (V/iii/31); even more explicitly, "the island was Helen" (XIX/iii/103).

4 I am only too aware of the strictures of Nabokov (1983:288): "All art is in a sense symbolic; but we say 'stop, thief' to the critic who deliberately transforms an artist's subtle symbol into a pedant's stale allegory." 
as they

crammed next to each other on its animal hide

were sliding into two worlds without switching gears.

One atavistic, with its African emblem

... and the other, world that shot them

to an Icarian future they could not control.

(XXII/i-ii/116f.)

Helen is first Achille's woman, then goes' to Hector, but on his death returns to Achille; Plunkett, obsessed by the colonial past of the island, admires Helen from afar, seeing an "historic hallucination" in her name:

Helen needed a history,

that was the pity that Plunkett felt towards her.

Not his, but her story.

\section{$(\mathrm{V} / \mathrm{iii} / 30)$}

The narrator, his travels through the Old World ended, makes the transition from a 'wrong love' for a European woman of Greek descent to a love "common as dirt" (XLIX/iii/250), which embraces all the simple sights and people of St Lucia, including Helen.

Omeros is also 'about' the difficulty of achieving an identity for those displaced by exile, or forcibly removed to a strange land by the slave trade. The deep division this has caused, and continues to cause, in the personality 5 is expressed through the notion of being wounded, associated with most major characters of the poem: the narrator (XIII/iii/76; XXXIII/ii/171), Achille, Hector. It is especially Philoctetewho suffers from an actual wound on his shin, originating from the sea, cured only towards the end of the poem by an African traditional remedy-who focuses, Christ-like, the historical suffering of all his people. ${ }^{6}$ In the case of Plunkett, the narrator makes the postmodern gesture, drawing attention to what he is doing, selfconsciously unveiling the cleft covered by the fiction of personality:

This wound I have stitched into Plunkett's character.

He has to be wounded, affliction is one theme

of this work, this fiction, since every ' $\mathrm{I}$ ' is a

fiction finally.

(V/ii/28)

5 Walcott's earlier poem, Laventville, evokes powerfully the deep wounds, the sense of historical amnesia, inflicted by slavery: "some open passage has cleft the brain, / some deep, amnesiac blow. We left / somewhere a life we never found" (Walcott 1992:29).

6 See especially III/iii/19: "[Philoctete] believed the swelling came from the chained ankles / of his grandfathers. Or else why was there no cure? / That the cross he carried was ... / that of his race." 
The loss of identity experienced by the islanders goes together with that sense shared by all colonized peoples, and encouraged by their colonizers, that they have no history. The poem keeps returning to this issue, asking insistently: "Who decrees a great epoch?" (XXXVIII/iii/196). Who belongs in the history books? What constitutes history-monuments and battles, ${ }^{7}$ or the lives of people? In St Lucia, "For those to whom history is the presence / of ruins, there is a green nothing" (XXXVII/iii/192). The narrator sees it as the task of his poetry to give a voice to the voiceless, those anonymous slaves and their descendants by whose labour the island was built up. ${ }^{8}$ (The poem also sympathetically depicts the expatriate Plunkett's need to find a history for his adopted country, even though his interest is exclusively in (St) Helen's colonial past $(\mathrm{XI} / \mathrm{i} / 64)$.) They are represented in Omeros by the long lines of women the narrator remembers from his youth, toiling up mountains of anthracite with loaded baskets on their heads. His father's shade tells him, this "is the chance you now have, to give those feet a voice" (XIII/iii/76).

Unlike a work such as Ulysses, which uses the Odyssey in a covert way, Omeros displays its relationship to Homer and the Classics quite openly, as a deliberate part of its poetic strategy. The major, classical, organizing element in the poem is, of course, the whole mythic cycle of the Trojan War, and its most important poet, Homer. (The poets who keep appearing in the text-Omeros, the blind singer Seven Seas, a river griot, a Sioux shaman-are all pictured as avatars of Homer; see especially LXIII/ii/318.) The reader is constantly invited to measure Achille against Achilles, Philoctete against Philoctetes, Hector and Helen against their classical counterparts, the wandering narrator against Odysseus, the events in Castries against those in Troy.

The classical Philoctetes suffered from a leg-wound that prevented him from being an archer and that led to his being exiled on an island, until he was miraculously cured, gained a (new) bow, and was re-integrated into heroic society. So too the St Lucian Philoctete has a suppurating wound on his shin that prevents his working as a fisherman, is 'exiled' on an island from his ancestral home in Africa, until he too is cured and regains his fisherman's oar: "and the bow leaped back to the palm of the warrior" (XLIX/ii/247). ${ }^{9}$ Heroic associations with warriors and

7 At XL/iii/205 the narrator's experience of Europe is of a a vanity whose / spires and bells punctually pardoned itself / in the absolution of fountains and statues, / in writhing, astonishing tritons; their cold noise / brimming the basin's rim, repeating that power / and art were the same $\ldots$ / Tell that to a slave from the outer regions / of their fraying empires".

8 The portrait of the English admiral, Rodney, appears in the St Lucian history books, "but the builders' names are not there, / not Hector's ancestor's, Philoctete's, nor Achille's" (LXII/iii/315).

9 I have learned a good deal about Philoctete and his role in Omeros from the paper by J. du P. Boeke, "The Use of Greek Source Material in Derek Walcott's Omeros", unpublished MA long essay, Stellenbosch 1995. 
weaponry recur throughout Omeros in connection with Achille and Hector, and an intricate web of mythic allusions surrounds them. Like the classical Achilles, Achille has 'myrmidon' ancestors, ${ }^{10}$ and struggles with Hector over the beautiful and enigmatic Helen. As the heroes had run around the walls of Troy, Achille and Hector race in a "marathon six times round the village" and "the true bounty was Helen" (V/iii/32). The St Lucian Hector has his "chariot" (XXII/ii/117), and, as in the Iliad, his death is one of the major events of the latter part of the poem. Plunkett for his part is entranced by the mythic parallels that he perceives between the wars fought over Greek Helen and Caribbean St Helen, especially the fact that the defeated French flagship at the decisive "Battle of the Saints" was called Ville de Paris.

Homer's Odyssey too-filtered in part through Joyce's Ulysses-colours a considerable part of Omeros. Maud Plunkett on her island, like Penelope on Ithaca, stitches away at a quilt (Taplin 1991:221). As Bloom-Odysseus in Ulysses finds in Steven-Telemachus the son he never had, so there is a suggestion that the childless Plunkett finds a 'son' in the narrator: 'but there in that khaki Ulysses [Plunkett] / there was a changing shadow of Telemachus / in me" (LII/iii/263). Both Achille and the narrator in turn are assimilated to Odysseus. In the dream-sequence of chapters XXIV and XXV Achille "comes home" to Africa, guided by a sea-swift sent by God, and is greeted as a "warrior returning from his battle". The only explicit allusion here to the Odyssey is the phrase "unbroken breakers, Ithaca's or Africa's" (XXIV/ii/130), but the general parallel is clear. ${ }^{11}$ The narrator wanders for years away from his small island, is told "before you return, you must enter cities" (XXXVI/iii/187), pictures himself an Odysseus sailing the Aegean/Caribbean with a disaffected African crew (XL/i-ii/201ff.), and finally at the start of Book 6 remembers his home with the phrase "a sail towards Ithaca", and returns.

Walcott does not allude to Virgil's Aeneid as openly as he does to the epics of Homer, 12 but the presence of the Roman poem, in particular Book VI, is felt at a number of crucial points in Omeros. Aeneid VI, a katabasis, a descent into another world, constitutes both the actual and the symbolic centrepoint of the Aeneid, in which the hero reviews his past, encounters its most significant figure, his father, is guided by him, and achieves the spiritual freedom to move forward into the future. Different aspects of this structure are reflected in Omeros, in the experience both of the narrator and of Achille.

Just as the spirit of Aeneas' dead father, Anchises, shows him a future which is at the same time the past of Rome, indicating his duty, so in Omeros chapters XII

10 The poem sets up a complex chain of associations between the toiling women coal-bearers, ants, and 'myrmidons', recalling the ancient association between 'Myrmidon' and the Greek for ant, myrmex (see esp. XIII/ii-iii/73ff., and XLVII/iii/239: "ants, the ancestors of Achille").

11 One recalls the guiding role of the goddess, Leucothoe, who appears to Odysseus in the guise of a bird in Od. 5, and Athene's bird-epiphanies in Od. 1 and 22.

12 His only explicit citation of the Aeneid is at $\mathrm{LX} / \mathrm{i} / 301$ : Achille searches for new fishing grounds, "some cove he could settle like another Aeneas, / founding not Rome but home, to survive in its peacen. 
and XIII the shade of the narrator's father guides him through his past, the places of his boyhood, and points out to him the poetic tasks that he must undertake (Minkler 1993:275, with n.18). The shade appears again to the narrator in XXXVI/iii/186f. (note the occurrence of a kind of leitmotiv in both passages "a sail leaving harbour and a sail coming in"), this time directing him home from exile (just as Aeneas is directed to his new 'home' in Italy).

At the very centre of Omeros (chapters XXV-XXX) we find a katabasis, a sunstroke-induced dream-journey in which Achille goes home to Africa, encounters his father and his past, and sees a tragic future of slavery. As in Aeneid VI we get a complex interweaving of the present with a future which is, from poet's and reader's point of view, the past: Achille "heard the griot muttering his prophetic song / of sorrow that would be the past" (XXVIII/i/148).

Omeros invokes the Classics openly and often. But these passages are balanced by others, almost as numerous, which express disquiet about aspects of the classical past, or reject outright the practice of viewing the present through the filter of the Classics. The narrator shows his awareness that Greece and Rome were slave-owning societies, that Rome had its own oppressive empire, that the ideals of order and rationality which the classical world bequeathed to the West had their sinister side. Travelling through the American South he observes: "how Greek it was, the necessary evil / of slavery ... / ... the Jeffersonian ideal in / plantations with its Hectors and Achilleses / ... towns named Helen, / Athens, Sparta, Troy" (XXXV/i/177). ${ }^{13} \mathrm{He}$ compares the situation of black slaves in the South-with its cultural institutions and "pillared façade that looked down on the black / shadows that they cast as an enraging nuisance" (XLI/i/206)-to that of Greek slaves in the Roman empire.

Doubts about the appropriateness of viewing St Lucia and her people through a classical lens emerge quite early on in the poem. Plunkett's identification of Helen with St Helen/St Lucia, and of the "Battle of the Saints" with the war at Troy, are termed an "historic hallucination", then a "mythical hallucination" (V/iii/31). And within this same section of the poem we read of the island's "village Olympiad", only to be told three lines later, "It wasn't Aegean. They climbed no Parthenon / to be laurelled." But the most sustained questioning of all classical and Homeric parallels comes at the end of the poem, as the narrator asks:

13 Cp.: "the Attic ideal of the first slave-settlement" (XI/i/63). 
Why not see Helen

as the sun saw her, with no Homeric shadow ...?

...

All that Greek manure under the green bananas,

... When would the sails drop

from my eyes, when would I not hear the Trojan War

in two fishermen cursing in Ma Kilman's shop?

When would my head shake off its echoes like a horse

shaking off a wreath of flies? When would it stop, the echo in the throat, insisting, 'Omeros';

when would I enter that light beyond metaphor? ${ }^{14}$

(LIV/ii-iii/271)?

Towards the end of the poem the narrator-poet's view of Omeros/Homer seems to change, and the Odyssey, poem of the sea, appears to gain the ascendancy over the lliad. The true importance of Omeros for him now is not as a source of forced classical comparisons (Caribbean Helen and Greek Helen, St Lucia and Troy), but rather as a poet of the blank unmetaphoric ocean:

The ocean had

no memory of the wanderings of Gilgamesh, or whose sword severed whose head in the Iliad.

It was an epic where every line was erased

yet freshly written in sheets of exploding surf ...

... It never altered its metre

to suit the age, a wide page without metaphors.

Our last resort as much as yours, Omeros.

$(\mathrm{LIX} / \mathrm{i} / 296)$

In the last chapter of Omeros the poet-narrator draws attention to the fact that his poem, if an epic at all, is a new type of epic, which has run counter to the norms of the genre. Instead of asking the Muse to sing at the start, as in lliad and Odyssey, the poet announces at the end the subject he has sung; and this is not an Iliadic Achilles, but Achille, a man who was not motivated by anger, who killed nobody:

14 See also the questioning of the whole Helen of St Lucia/Helen of Troy parallel at LXII/ii/312f. 
I sang of quiet Achille, Afolabe's son

$\ldots$
that brought him delight, and that from necessity-
of fish ...
whom no man dared insult and who insulted no one ...

(LXIV/i/320)

Omeros' ambivalent attitude to the Classics persists almost to its final page. In this same last chapter (LXIV/ii) the poet-narrator speaks again of the Homeric echoes that had haunted him "for three years", and which he seems now to have exorcized. Yet almost immediately thereafter the echoes recur: "the Cyclops's flock, / with the smart man under one's belly", "the rock / of Polyphemus", "Omeros".

\section{IV}

What is the reader to make of this thoroughgoing ambivalence in Omeros, this constant oscillation between attraction to and rejection of the Classics as an ordering principle, as an exemplar for contemporary experience? A number of answers can be offered to this question, each touching on a different level of the poem's meaning. At one fairly simple level Omeros is a form of autobiography-as is much of Walcott's earlier poetry. The experience of its poet-narrator touches at many points on that of the man, Derek Walcott, who is descended from a white grandfather and a black grandmother on both his father's and his mother's side, who learned Latin at school, and received a thorough colonial education in the European Classics (Hamner 1981:22). The doubts that characters in Omeros feel about seeing their world through a classical filter are Walcott's own doubts, expressed repeatedly in his earlier work. An example from his poem, "Homecoming: Anse La Raye":

Whatever else we learned

at school, like solemn Afro-Greeks eager for grades,

of Helen and the shades

of borrowed ancestors,

there are no rites

for those who have returned

$\cdots$

only this fish-gut reeking beach ...

(Walcott 1992:100)

At another level Omeros' ambivalence toward the Classics works as a metaphor for the dilemma of the postcolonial artist, in this case, the Caribbean author writing in

15 Right at the end of the poem we find "A triumphant Achilles [note the Greek spelling], / his hands gloved in blood" (LXIV/iii/324)-but it is only the blood of fish. 
English. The dilemma is familiar: such a writer tries to express to an international readership the reality of his postcolonial world, and does so in English; yet to what degree, if at all, is the imported language of the colonizer adequate to his task, to what extent does it distort and deny the very experience it seeks to convey? The imported form of Omeros, with its echoes of the European epic tradition from Homer to Joyce, the poem's hungry appropriation, then rejection, of Greek mythical paradigms, are all, I would suggest, metaphorical expressions of this dilemma. Omeros' subversion of its Classical models is at the same time a questioning of the adequacy of all European forms to convey the reality of Caribbean experience. ${ }^{16}$ Just as with his chosen language, English, 17 the poet-narrator can neither fully accept these forms, nor can he shake himself free of their influence.

Finally, at the deepest level, Omeros expresses-through its uneasy relationship with some of the greatest poetry ever composed, that of Homer-ambivalence about the role of metaphorical language, about the role of poetry itself. The doubts emerge especially in the later sections of the poem, where the narrator wonders about having made "fake African masks for a fake Achilles" (XLV/ii/228), asks "Who needed art in this place"? (XLV/ii/229), and reflects on the insidious artistic "process by which men are simplified" (LIX/iii/298). The photographing of Achille by tourists and his consequent anger-"It was the scream of a warrior losing his only soul / to the click of a Cyclops" (LIX/iii/299)-can be seen as an image for what the poet himself has done with Achille, expressed ironically through a Homeric metaphor.

Already in Walcott's earlier poetry paradoxical longings appeared for "the style past metaphor" (Walcott 1992:117). ${ }^{18}$ They surface again in Omeros, but are now connected with the struggle against Classical exemplars. In passages quoted earlier the narrator asks when he will stop hearing those Homeric echoes and "enter that light beyond metaphor" (LIV/ii-iii/270f.); and he tries to elevate the ocean to a status above all literary imaging: "a wide page without metaphors. / Our last resort as much as yours, Omeros" (LIX/i/296). But this is, of course, a self-defeating task: the poet has to use metaphor ("wide page") even as he rejects its use. He can no more dispense with metaphor than he can dispense with the Classical paradigms and the Homeric echoes that haunt him. ${ }^{19}$

16 Part of what makes Omeros a great poem is the thoroughness with which its project is carried through. The ambivalence we are speaking of extends right down into its language and metrical form. The diction of the poem ranges from the Greco-Roman-'anabasis', 'stasis', 'Dominus illuminatio mea'-through Caribbean dialect to words such as 'shat' and 'fockin'. And its verse-form is basically a Dantesque terza rima-but one constantly unsettled by unusual rhymes and half-rhymes.

17 The narrator speaks of the English of Plunkett and his countrymen as "the wound of a language I'd no wish to remove" (LIV/i/270).

18 Cp. also: "I seek / As climate seeks its style, to write / Verse crisp as sand, clear as sunlight, I Cold as the curled wave, ordinary / As a tumbler of island water" (from the poem, Islands, in Walcott 1962:77).

19 I gratefully acknowledge the financial support of the CSD for the research leading to this article. The views expressed here are, of course, my own and not those of the CSD. 


\section{BIBLIOGRAPHY}

Breslow, S 1993. Derek Walcott: 1992 Nobel Laureate in Literature. World Literature Today 67, 267-271.

Brown, S (ed.) 1991. The Art of Derek Walcott. Chester Springs, Pa.: Dufour.

Dassenbrock, R W 1994. Constructing a Larger Iliad: Ezra Pound and the Vicissitudes of Epic. In Oberhelman, S M et al. (eds.), Epic and Epoch: Essays on the Interpretation and History of a Genre, 248-266. Lubbock: Texas Tech U.P.

Hamner, R D 1981. Derek Walcott. Boston: Twayne.

Mason, D 1991. Poetry Chronicle. The Hudson Review 44, 509-518.

Minkler, J A 1993. Helen's Calibans: A Study of Gender Hierarchy in Derek Walcott's Omeros. World Literature Today 67, 272-276.

Nabokov, V 1983. Lectures on Literature. London: Picador.

Pound, E 1954. Literary Essays of Ezra Pound, ed. T S Eliot. London: Faber.

Said, E 1994. Culture and Imperialism. London: Vintage.

Steiner, G 1993. From Caxton to Omeros. TLS, August 27, 13-16.

Taplin, O 1991. Derek Walcott's Omeros and Derek Walcott's Homer. Arion 3rd Series 1.2, 213-226.

Walcott, D 1962. In a Green Night: Poems 1948-1960. London: Jonathan Cape.

Walcott, D 1990. Omeros. London: Faber.

Walcott, D 1992. Poems 1965-1980. London: Jonathan Cape. 